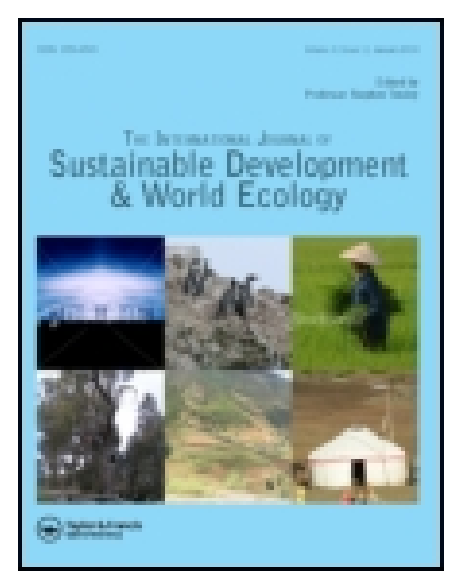

International J ournal of Sustainable Development \& World Ecology

Publication details, including instructions for authors and subscription information:

http:// www. tandfonline.com/loi/tsdw20

\title{
Simulating the impacts of land-use changes on non-point source pollution in Lugu Lake watershed
}

Xue Bai , Ke-Ming Ma , Liu Yang \& Xiao-Lei Zhang

Published online: 20 Sep 2010.

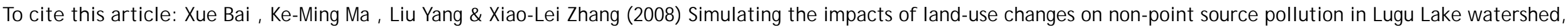
International J ournal of Sustainable Development \& World Ecology, 15:1, 18-27, DOI: 10.1080/ 13504500809469764

To link to this article: http:// dx.doi.org/ 10.1080/13504500809469764

\section{PLEASE SCROLL DOWN FOR ARTICLE}

Taylor \& Francis makes every effort to ensure the accuracy of all the information (the "Content") contained in the publications on our platform. However, Taylor \& Francis, our agents, and our licensors make no representations or warranties whatsoever as to the accuracy, completeness, or suitability for any

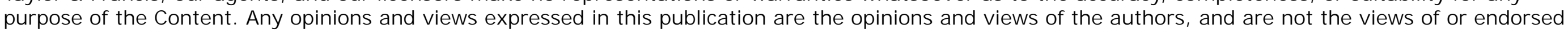

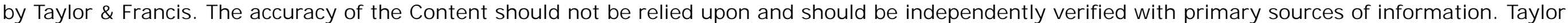

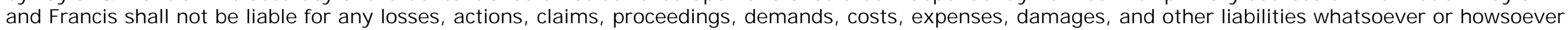
caused arising directly or indirectly in connection with, in relation to or arising out of the use of the Content.

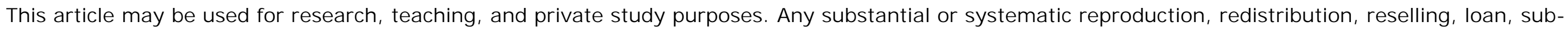
licensing, systematic supply, or distribution in any form to anyone is expressly forbidden. Terms \& Conditions of access and use can be found at http:// www.tandfonline.com/page/terms-and-conditions 


\title{
Simulating the impacts of land-use changes on non-point source pollution in Lugu Lake watershed
}

\author{
Xue Bai ${ }^{1,2}$, Ke-Ming Ma ${ }^{2}$, Liu Yang ${ }^{2,3}$ and Xiao-Lei Zhang ${ }^{1}$ \\ ${ }^{1}$ Institute of Xinjiang Ecology and Geography, Chinese Academy of Sciences, Urumqi, China \\ ${ }^{2}$ State Key Laboratory of Urban and Regional Ecology, Research Center for Eco-Environmental \\ Sciences, Chinese Academy of Sciences, Beijing, China \\ ${ }^{3}$ School of Resource and Safety Engineering, China University of Mining and Technology, \\ Beijing, China
}

Key words: Land-use change, non-point source pollution, L-THIA, water quality

\begin{abstract}
SUMMARY
Protection of the water quality of Lugu Lake is important because it is a unique geographic and cultural resource. Not only point source pollution but also non-point source pollution contribute to degradation of water quality. A GIS-NPS model, with long-term hydrologic impact assessment (L-THIA), was used to evaluate long-term implications of land-use change impacts on non-point source (NPS) pollution. The land-use patterns of 1995 and 2005 were analysed to determine the changes in Lugu Lake watershed. A 30-year (1974-2003) precipitation dataset was used to estimate mean annual surface runoff and NPS pollutant loads. The contributions of different land-use categories to average annual runoff and NPS pollutant production were assessed with a unit contribution index (UCI). Results show loss of agricultural land (by $44.9 \%$ ), while forest, grass/pasture and residential land increased to different degrees from 1995 to 2005. At the same time, annual average NPS pollutants, TN, TP, TSS and BOD loads all decreased, while heavy metal lead increased by $6.87 \%$. The UCI formulated in this research was a more useful method to assess land-use impact on NPS pollutants than simple investigations of the percentage land-use change. Agricultural and residential land changes had more impact on NPS pollutants and were identified as the main source types. Suggestions on regulating land uses and management proposals for protecting lake water quality in Lugu Lake watershed are made.
\end{abstract}

\section{INTRODUCTION}

Rapid socio-economic development in China is often at the cost of natural environment degradation and loss of ecological functions, especially water resource pollution. Water pollution results from both point and non-point sources (NPS)

Point source pollution occurs at identifiable point outlets, e.g. pipes, drains, drums, and tanks that enter waterways at discrete, identifiable locations and can usually be monitored. NPS pollution is more difficult to identify and measure because it

Correspondence: Ke-ming Ma, State Key Laboratory of Urban and Regional Ecology, Research Center for Eco-Environmental Sciences, Chinese Academy of Sciences, 18 Shuangqing Road, Haidian District, Beijing 100085, China. Email: mkm@rcees.ac.cn 
originates from diffuse sources, spread over a larger area, such as runoff from streets and parking lots, salt from roads, sediment-laden loss from construction sites, and wet and dry atmospheric deposition.

The most significant human impacts on the hydrologic system are caused by land-use change (Fisher et al. 2000; Wang 2001). It is well understood that conversion of land to agricultural, industrial, commercial or residential uses significantly alters the hydrologic characteristics of the land surface and modifies pathways and rates of water flow (Ren et al. 2003; Pauleit et al. 2005). The land-use pattern is increasingly disturbed by human activity. Many regions in China have various environmental pollution issues to different extents, such as water quality degradation due to illogical land-use management therefore, it is essential for hydrologic system health and sustainable regional development to assess impacts of land-use change on lake water quality. The issue of spatial scale in runoff and NPS pollution assessment is extremely important because both runoff and NPS pollution are produced as a function of land use and precipitation, both of which have strong and inherent spatial characteristics. Previous researchers failed to associate land-use decision making processes with water quality management and sustainable regional development until recently. Neglecting hydrological impacts of land-use change may lead to unexpected flooding, stream and lake degradation, erosion and loss of groundwater supply (Harbor 1994). It is thus important for decision makers to be conscious of information on the cumulative hydrologic impacts of land-use change at local or regional levels. As some correlation exists between pollution load and land use, it is always possible to improve water quality with proper land-use management if the role of different land uses within a contributing area is known (Perry and Vanderklein 1996; Basnyat et al. 1999).

The watershed of Lugu Lake is part of the famous national travel area, the Jade Dragon Jokul of Lijiang, Yunnan Province. Together with more and more tourists, water quality protection has attracted attention of both scholars and government. In order to prevent water quality degradation in advance, this study aimed to determine the relationship between different land uses and NPS pollutants by using a quantitative method. The water quality can then be manipulated by making rational use of land. This paper first examines the changing patterns of land use between 1995 and 2005 within Lugu Lake watershed. It then provides an analysis of land-use impacts on water quality in terms of NPS pollution. The paper concludes with suggestions on lake water quality protection and the directions for future research.

Previous studies showed that both agricultural and impervious land uses are known to have major impacts on water quality by producing many NPS pollutants (sediments, animal wastes, plant nutrients, pesticides) (Viessman and Hammer 1993; Bhaduri et al. 2000; Wang 2001; Pauleit et al. 2005). NPS pollution caused by land-use change had been identified as an important cause of surface water quality degradation (Ren et al. 2003; Yin et al. 2005). Hydrologic models, together with a geographic information system (GIS) and remote sensing (RS) had been applied and proved to be powerful techniques in studying the hydrologic impacts of land-use change (Wang and Deal 2005; Conway and Lathrop 2005; Pauleit et al. 2005). The pioneer studies provided much valuable information in understanding the relationship between land-use change and NPS pollution.

Hydrologic and NPS water quality models include either single-storm event models (AGNPS, ANSWERS, DWSM KINEROS) or long-term simulation hydrologic models (AnnAGNPS, HSPF, SWAT), or combination models of both capabilities (CASC2D, L-THIA, MIKE SHE, PRMS) (Borah and Bera 2003). Compared to single storms, minor precipitation events and annual runoff level are more valuable in terms of groundwater recharge and wetland hydrology (McClintock et al. 1995; Leitch and Harbor 1999). Furthermore, information for long-term hydrologic impacts of land-use change is vital for land-use planning and NPS pollution control. According to the intended use, required accuracy, data availability and study area characteristics (McKillop et al. 1999; Wang and Deal 2005), the long-term hydrologic impact assessment (L-THIA) model, a GIS-based export coefficient model, was selected in the present research. Information on land-use change was provided from remote sensing images for 1995 and 2005. The NPS pollutants load was calculated from the land-use change information in the L-THIA model. A unit contribution index (UCI) method was finally applied to quantify the impacts of different land uses on NPS pollution. 


\section{METHODS AND MATERIALS}

\section{Study area}

The study area, Lugu Lake, is described in the Introdution. The lake has a water area of $50.5 \mathrm{~km}^{2}$ a watershed area of $247.6 \mathrm{~km}^{2}$, a volume of $22.5 \times 108 \mathrm{~m}^{3}$, the ratio of watershed area to lake area is 3.82 , the water residence time is 18.5 years and the annual water discharge is $1.1 \times 108 \mathrm{~m}^{3}$ (Wan 1988). The Lugu Lake area has a potential evapotranspiration of $1270 \mathrm{~mm}$. It is a semi-closed deep fault lake in the Jinshajiang River drainage area. The watershed is mainly limestone, mud stone and sandstone. Soils include Alfisols, Oxisols, Entisols and Mollisols. Forest coverage is $47.6 \%$.

\section{Hydrologic and water quality model}

The long-term hydrologic impact assessment (L-THIA) model was applied to estimate the annual average runoff and NPS pollutants load in the watershed of Lugu Lake in 1995 and 2005. The model was originally developed as a relatively simple runoff and NPS pollutants calculation technique to generate a measure of the long-term potential hydrologic impact of land-use change (Harbor 1994). It provides quick and accessible impact analysis for different land-use scenarios with analysis of potential long-term problems for the community (Harbor 1994; Bhaduri et al. 2000 Pandey et al. 2000). The L-THIA approach uses the curve number $(\mathrm{CN})$ method for calculating runoff and NPS pollutants, and was selected because it is used as a core component of many more sophisticated hydrologic models, yet requires only readily available data (soil type, land use and climate data) The CN method is an empirical set of relationships between rainfall, land-use characteristics and runoff depth. The basic equation for runoff calculation is

$$
\mathrm{Q}=\frac{(P-0.2 S)^{2}}{(P+0.8 S)}
$$

where $Q$ is runoff (in), $P$ is rainfall (in), and $S$ is potential maximum retention after runoff begins (in). $S$ is related to soil and land-cover conditions of the watershed through $\mathrm{CN}$, which ranges from 0 to 100. $S$ is related to $\mathrm{CN}$ by

$$
\mathrm{S}=\frac{1000}{C N}-10
$$

where $\mathrm{CN}$ is the curve number.
ArcView GIS software (ESRI 1999) was chosen for the L-THIA/NPS GIS application. This requires input data for long-term precipitation (in terms of daily rainfall), hydrologic soil group and land-use combinations. When the prepared data in grid format were put into the model in ArcView3.2, it could compute the distributed CNs. Runoff volume and NPS pollutant load of every cell in the grids were then calculated. L-THIA divides the study area into grid cells and takes land use and hydrological soil group information for each cell to calculate $\mathrm{CN}$ at each cell. It then employs daily rainfall series and the CNs to calculate the mean annual total surface runoff, both in terms of depth and volume. NPS pollutant load can be estimated from the runoff volume and event mean concentration (EMC) NPS data.

\section{Precipitation data}

The daily rainfall for 30 years in the study area, from 1974 to 2003, was acquired from the Meteorological Information Center of the China Meteorological Administration. The precipitation series for the period was prepared in text file format according to the L-THIA model conventions. To do so, a matrix of daily rainfall (inches) with 366 rows and 30 columns was input into Excel and saved as a tab-delimited text file with an extension of *.txt.

\section{Land-use data}

Landsat TM (resolution of $30 \mathrm{~m}$ ) multispectral images were used as the main sources to estimate land uses in 1995 and 2005. The images, from the China Remote Sensing Satellite Ground Station (RSGS), were acquired on 11 January 1995 and 6 January 2005. Relief maps of 1:50000 (mapped in 1966 by the General Staff Mapping Bureau) and land-use type map of 1:25000 of Ninglang County (mapped in 1994 by the Land Administration Bureau of Ninglang County) were used as references in land-use data processing.

The relief maps were first scanned into JPEG data using an EPSON perfection 4870 scanner. They were then imported into the image processing software-ERDAS IMAGINE ${ }^{\mathrm{TM}}$ (ERDAS, Atlanta, GA), geo-referenced to themselves and combined in an image mosaic model. Second, relief maps were digitised in Arcinfo8.1 to produce a contour map $(20 \mathrm{~m})$ of the study area. The 1:50000 digital elevation model (DEM) was then developed 
using the 3D analysis model in Arcinfo8.1. Third, Landsat TM images were also imported and geo-corrected into a coordinate system-Gauss Kruger, D_Krasovsky_1940 Datum, taking the electronic relief map as the reference image. RMS errors were both smaller than 0.5 pixels. Fourth, according to DEM data, the watershed boundary of Lugu Lake was created using a soil and water assessment tool model (SWAT). Then, the watershed of Lugu Lake in images of both 1995 and 2005 was clipped by the subset model in ERDAS. Fifth, the land uses in 1995 and 2005 were mapped using a supervised classification method in ERDAS classifier model. Since residential and industrial areas have similar spectral responses in TM imagery, they were grouped together during the land-use classification process for the land-use change analyses of 1995 and 2005. There were then five land uses derived from the images in the study area: agricultural, forest, grass/pasture, residential/industrial and water. Finally, the land-use data estimated from 2005 Landsat TM were calibrated through fieldwork to achieve better precision. The land-use classification from 1995 could not be calibrated by field survey data and supplementary data were used in its land-use calibration. Both land-use datasets were converted into shapefile format (Fig. 1).

\section{Hydrologic soil data}

Soils were classified into hydrologic soil groups (HSGs) to indicate the minimum rate of infiltration obtained for bare soil after prolonged wetting (TR-55). The HSGs, together with land use, were elements used in determining runoff curve numbers (CNs). According to the description of HSGs (Table 1), soils of Lugu Lake watershed were classified into hydrologic soil group A, B, C and D. The HSG shapefile data were then created in ArcGIS 8.1 (ESRI 2001) (Fig. 2).

One point should be mentioned, "Recls_land" and "Recls_hsg" fields must be contained in the land use and soil themes, respectively, following the L-THIA conventions (Engel 2003). Since the landuse type of residential/industrial in the study was different from that required by L-THIA, the curve number text file from the L-THIA program package was modified correspondingly (Table 1 ).

\section{Mathematical analysis}

The changes in land use and lake water quality (including annual runoff volume and NPS pollutant loads) were calculated so as to explore the long-term impacts of land-use changes on water quality. The changes in land-use categories (Table 2) and their distribution for 1995 and 2005 in Lugu Lake (Fig. 3) were achieved with Microsoft Excel. Moreover, to assess changes in runoff volume and NPS pollutant loads between 1995 and 2005, the total amounts of these should be obtained. Therefore, the runoff volume and NPS pollutant loads of every cell was multiplied by the respective count of cells. The indicators of NPS pollutants to be

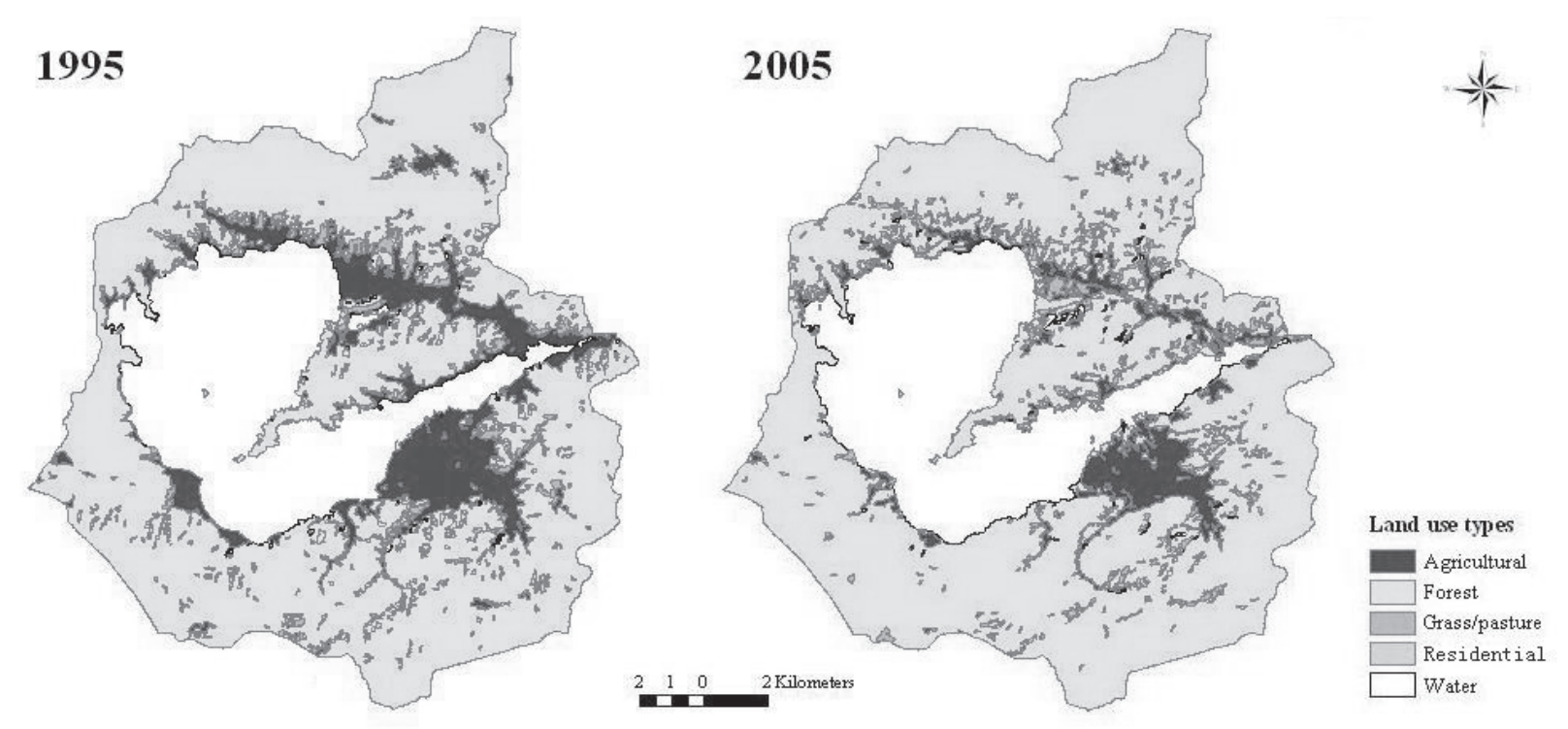

Figure 1 Land-use distribution in 1995 and 2005 in Lugu Lake watershed 
Table 1 Land-use categories in the study area and their associated curve numbers

\begin{tabular}{lcccc}
\hline & \multicolumn{4}{c}{$\begin{array}{c}\text { Curve number for hydrologic } \\
\text { soil group }\end{array}$} \\
\cline { 2 - 5 } Land use & $A$ & $B$ & $C$ & $D$ \\
\hline Agricultural & 67 & 78 & 85 & 89 \\
Forest & 36 & 60 & 73 & 79 \\
Grass/pasture & 39 & 61 & 74 & 80 \\
Residential/industrial & 66 & 78 & 81 & 89
\end{tabular}

Table 2 Changes in land use categories in Lugu Lake watershed between 1995 and 2005

\begin{tabular}{lrrc}
\hline & \multicolumn{2}{c}{ Year $\left(\mathrm{km}^{2}\right)$} & Change (\%) \\
\cline { 2 - 4 } Land use & 1995 & 2005 & $1995-2005$ \\
\hline Agricultural & 28.42 & 15.66 & -44.90 \\
Forest & 150.25 & 159.39 & 6.08 \\
Grass/pasture & 6.82 & 10.15 & 48.83 \\
Residential & 0.12 & 0.36 & 200.00 \\
\hline
\end{tabular}

Table 3 Changes in annual average estimated runoff volume and NPS pollution loads from Lake Lugu watershed between 1995 and 2005

\begin{tabular}{llccc}
\hline & & \multicolumn{2}{c}{ Year } & Change (\%) \\
\cline { 3 - 5 } \multicolumn{2}{l}{ Pollutant } & 1995 & 2005 & $1995-2005$ \\
\hline Runoff & $\left(\times 10^{6} \mathrm{~m}^{3}\right)$ & 7.26 & 7.16 & -1.38 \\
TN & $\left(\times 10^{3} \mathrm{~kg}\right)$ & 9.68 & 6.91 & -28.62 \\
TP & $\left(\times 10^{3} \mathrm{~kg}\right)$ & 1.68 & 0.74 & -55.95 \\
TSS & $\left(\times 10^{5} \mathrm{~kg}\right)$ & 1.39 & 0.62 & -55.40 \\
Lead & $\left(\times 10^{1} \mathrm{~kg}\right)$ & 3.20 & 3.42 & 6.87 \\
BOD & $\left(\times 10^{3} \mathrm{~kg}\right)$ & 8.07 & 5.65 & -29.99 \\
\hline
\end{tabular}

evaluated were selected based on the main water pollutants identified in Lugu Lake, including total nitrogen $(\mathrm{TN})$, total phosphorus (TP), total suspended solids (TSS), biochemical oxygen demand (BOD) and heavy metals (lead). These indicators were representatively identified as water quality pollutants (Novotny and Olem 1994; Pandey et al. 2000; Tang et al. 2005). The indicators mentioned above, together with annual runoff volume, were assessed by using L-THIA (Table 3 ).

To compare the impacts of different land-use categories on NPS pollutant loads, the unit contribution index (UCI) $\beta_{i j}$ was obtained as following:

$\beta_{i j}=\overline{\beta_{i j}}(t)=\operatorname{mean}\left(\beta_{i j}(t)\right)$

$\beta_{i j}(t)=p\left(N P S_{i j}(t)\right) / p\left(S_{i}(t)\right)=N P S_{i j}(t) / c_{j}(t) S_{i}(t)$

$$
c_{j}(t)=\sum_{t=1}^{n} N P S_{i j}(t)
$$

For $i=1, \ldots, n, j=1, \ldots, m, t=1, \ldots, l, \beta_{i j}$ is the mean value of $\beta_{i j}(t)$ in lyears in equation (3). In equation (4), $\beta_{i j}(t)$ is the unit contribution degree of land use category $i$ to NPS pollutant $j$ in time $t, p\left(N P S_{i j}(t)\right)$ is the contribution (\%) of land-use category $i$ to NPS pollutant $j$ in time $t ; p\left(S_{i}(t)\right)$ is the proportion (\%) of land-use category $i$ in time $t ; N P S_{i j}(t)$ is the estimated loads of NPS pollutant $j$ by land-use category $i$ in time $t ; S_{i}(t)$ is the area of land-use category $i$ in time $t$. In equation (5), $\sum_{i=1}^{n} N P S_{i j}(t)$ is the total loads of NPS pollutant $j$ by $n$ land-use categories in time $t$; $\sum^{n} S_{i}(t)$ is total area of $n$ land-use categories in time $i=c_{j}(t)$ is a constant for the same NPS pollutant in time $t$. The UCI $\beta_{i j}$ were calculated according to equations (3), (4) and (5) (Table 5).

Table 4 Contribution (\%) of land-use categories to estimated annual average runoff volume, total nitrogen (TN), total phosphorus (TP), total suspended solids (TSS), lead and biochemical oxygen (BOD) demand pollution for Lake Lugu watershed

\begin{tabular}{|c|c|c|c|c|c|c|c|c|c|c|c|c|}
\hline \multirow[b]{2}{*}{ Land uses } & \multicolumn{2}{|c|}{ Runoff } & \multicolumn{2}{|c|}{$T N$} & \multicolumn{2}{|c|}{$T P$} & \multicolumn{2}{|c|}{ TSS } & \multicolumn{2}{|c|}{ Lead } & \multicolumn{2}{|c|}{$B O D$} \\
\hline & 1995 & 2005 & 1995 & 2005 & 1995 & 2005 & 1995 & 2005 & 1995 & 2005 & 1995 & 2005 \\
\hline Agricultural & 17.09 & 7.13 & 56.41 & 32.48 & 96.29 & 90.18 & 95.38 & 87.35 & 5.81 & 2.24 & 61.52 & 36.12 \\
\hline Forest & 78.73 & 86.26 & 41.35 & 62.55 & 3.41 & 8.40 & 4.11 & 9.88 & 89.23 & 90.23 & 35.43 & 54.65 \\
\hline Grass/Pasture & 4.09 & 6.31 & 2.15 & 4.58 & 0.18 & 0.61 & 0.21 & 0.72 & 4.64 & 6.61 & 1.84 & 4.00 \\
\hline Residential & 0.10 & 0.29 & 0.09 & 0.38 & 0.12 & 0.80 & 0.30 & 2.04 & 0.33 & 0.92 & 1.21 & 5.23 \\
\hline
\end{tabular}




\section{RESULTS}

\section{Land-use change}

There was an obvious change in land-use distribution during 1995 and 2005 in Lugu Lake watershed

Table 5 The unit contribution index (UCI) $\beta_{i j}$ of different land-use categories to annual average runoff volume and NPS pollutant loads

\begin{tabular}{lcccccc}
\hline Land uses & Runoff & $T N$ & TP & TSS & Lead & BOD \\
\hline Agricultural & 0.98 & 3.77 & 8.49 & 8.29 & 0.33 & 4.15 \\
Forest & 0.99 & 0.62 & 0.07 & 0.09 & 1.08 & 0.54 \\
Grass/Pasture & 1.13 & 0.71 & 0.08 & 0.10 & 1.24 & 0.62 \\
Residential & 1.52 & 1.67 & 2.99 & 7.57 & 4.92 & 22.80 \\
\hline
\end{tabular}

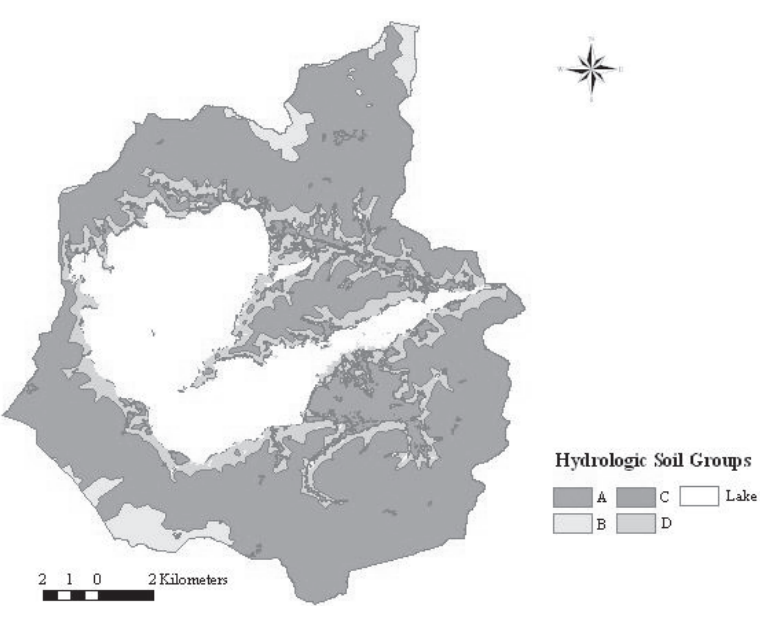

Figure 2 Hydrologic soil groups in Lugu Lake watershed

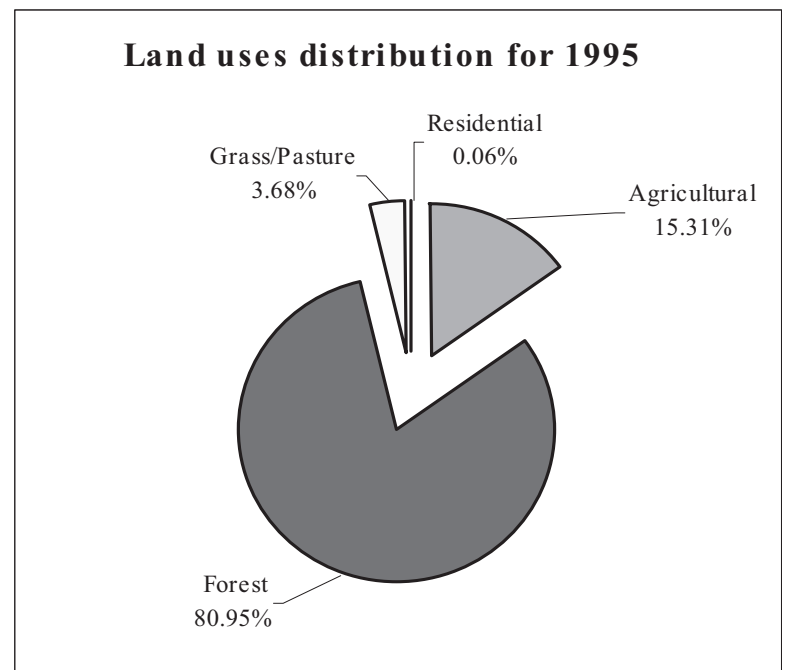

(Fig. 3). The prominent land-use change was that agricultural land decreased by $44.9 \%$, while the other uses increased (Table 2). Residential land increased most $(200 \%)$ and forest increased least $(6.08 \%)$. Forest land was still the dominant land-use type during these ten years $(80.95 \%$, $85.90 \%)$, followed by agricultural land $(15.31 \%$, $8.44 \%)$, grass/pasture land $(3.68 \%, 5.47 \%)$ and residential land $(0.06 \%, 0.19 \%)$, which accounted for a small proportion of the study area.

\section{Changes in NPS pollutants}

Average annual runoff and NPS pollutant loading also changed markedly in the watershed of Lugu Lake in 1995 and 2005. Apart from an increase in the average annual loading of lead by $6.87 \%$, runoff and other NPS pollutants all decreased to different degrees. TP and TSS reduced most, $55.95 \%$ and $55.40 \%$, respectively, followed by BOD (29.99\%) and $\mathrm{TN}(28.62 \%)$, and average annual runoff decreased least (1.38\%) during 1995-2005 (Table 3).

\section{Impacts of land-use changes on NPS} pollutants

There were some changes in contributions of different land uses to estimated annual average runoff volume and NPS pollutant loads during 1995 and 2005 (Table 4). In 1995, agriculture contributed most to annual average TN, TP, TSS and

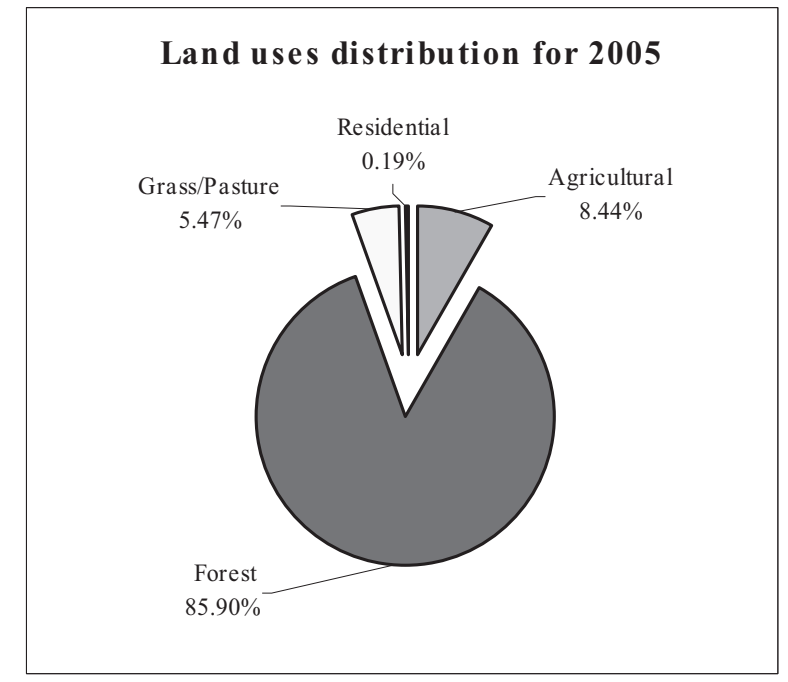

Figure 3 Land-use proportion in Lugu Lake watershed for 1995 and 2005 
BOD loads, $56.41 \%, 96.29 \%, 95.38 \%$ and $61.52 \%$, respectively. Forest contributed most to annual average runoff and lead loads, $78.73 \%$ and $89.23 \%$, respectively. Grass/pasture and residential land contributed less $(0.1-5.0 \%)$ to runoff volume and NPS pollutant loads. In 2005, agricultural land still contributed most to TP and TSS loads, $90.18 \%$ and $87.35 \%$, respectively. Forest also contributed most to TN and BOD loads, $62.55 \%$ and $54.65 \%$, respectively, besides annual average runoff volume $(86.26 \%)$ and lead loads $(90.23 \%)$. Grass/pasture and residential land contributed more to runoff and NPS pollutant loads than in 1995. The contribution of agricultural land to runoff volume and NPS loads all decreased. The decrease was highest for annual average loads of BOD (25.4\%), and TN (23.93\%) which were ranked second, followed by runoff $(9.96 \%)$, TSS $(8.03 \%)$, TP $(6.11 \%)$ and lead $(3.57 \%)$. The contributions of forest, grass/pasture and residential land to runoff volume and NPS loads all increased. The contributions of forest land to $\mathrm{TN}$ and BOD were $21.2 \%$ and $19.22 \%$, respectively. In short, contributions of agricultural land to annual average runoff volume and NPS pollutan loads were all reduced, while those of other land categories all increased between 1995 and 2005 in Lugu Lake watershed.

The unit contribution index (UCI) $\beta_{i j}$ of different land-use categories to annual average runoff volume and NPS pollutant loads showed that the strength of the impact of land uses on NPS pollutants were different (Table 5). The order of UCI $\beta_{i j}$ of land uses was residential (R) > grass/ pasture $(\mathrm{G})>$ forest $(\mathrm{F})>$ agricultural $(\mathrm{A})$ for annual average runoff volume, $\mathrm{A}>\mathrm{R}>\mathrm{G}>\mathrm{F}$ for $\mathrm{TN}$ TP and TSS, $\mathrm{R}>\mathrm{G}>\mathrm{F}>\mathrm{A}$ for lead and $\mathrm{R}>\mathrm{A}>\mathrm{G}>\mathrm{F}$ for BOD.

Among the UCI $\beta_{i j}$ between agriculture and five NPS pollutants, that between agriculture and TP was highest (8.49), followed by that between agriculture and TSS (8.29). Those between agriculture and BOD and TN were 4.15 and 3.77, respectively. The UCI $\beta_{i j}$ between agriculture and lead was least (0.33). For the UCI $\beta_{i j}$ for residential, that between residential and BOD was highest (22.8), followed by that between residential and TSS (7.57). The UCI $\beta_{i j}$ between residential and lead and TN were 4.92 and 1.67, respectively. However, the UCI $\beta_{i j}$ between forest and grass/pasture and NPS pollutants were all relatively smaller (Table 5).

\section{DISCUSSION}

\section{Land-use change and NPS pollution}

China has reached a distinct stage of development, especially since the 1980s. In order to achieve more socio-economic benefits, more and more land surfaces, especially "green" land, have been changed into impervious surfaces, such as concrete and rooftops. However, in the Lugu Lake watershed, forest and grass/pasture increased, corresponding to the decrease in agricultural land during 1995-2005. The Grain-for-Green programme initiated by the local government in 2003 probably contributed most to the land-use change trend from 1995 to 2005. Historically, deforestation is considered to be the main cause of water and soil erosion in other basins (Fu and Gulinck 1994). Deforestation and water loss are believed to be major causes of the devastating floods in China. Because of the floods and increasing soil erosion, in 1999 China's government has responded with nationwide cropland set aside, the Grain-for-Green programme (Uchida et al. 2004). According to this project, slope cropland of more than $25^{\circ}$ should be turned into forest or grass/pasture in order to maintain lake water quality. Therefore, forest and grass/pasture increased between 1995 and 2005 in the watershed of Lugu Lake, together with an increase in residential area.

Corresponding to the decrease in agricultural land, the annual average NPS pollutant loads showed a decreasing trend, except for the heavy metal, lead. Nutrients are typically identified as the non-urban pollutants and heavy metals are regarded as urban pollutants (Novotny and Olem 1994; Pandey et al. 2000; Tang et al. 2005). The results of this study showed that non-urban NPS pollution mitigated, and urban NPS pollution aggravated, to a small extent. The contributions and UCI $\beta_{i j}$ of land-use categories showed that different land uses impacted on NPS pollutants at different strengths. For the annual average NPS pollutant TP loads, the impact strengths of agricultural and residential were higher than forest, although forest accounted for more than half of the land area in the watershed. Residential land has important effects on runoff and NPS pollutants, especially BOD, TSS and lead (Bhaduri et al. 2000; Ren et al. 2003; Yin et al. 2005). Agricultural and 
residential were the contributing zones for NPS pollution. The UCI $\beta_{i j}$ between forest and grass/pasture land and NPS pollutants had a relatively small impact on NPS pollution. Forest and grass/pasture, therefore, could be taken as detention or absorption zones of NPS pollutants, which accords with the results from other research.

\section{Limitations of the study}

L-THIA, the hydrologic model, was utilised to estimate annual average runoff volume and NPS pollutant loads for 1995 and 2005 in Lugu Lake watershed. In order to simplify the runoff volume calculation process, there were three assumptions in L-THIA: 1) no influence of snowfall; 2) no consideration of ground freezing; and 3) no variety of antecedent moisture conditions (Engel 2003). There were no snowfall and ground freezing in the watershed and the third assumption could impose problems when daily series of runoff were simulated. However, the mean of annual total runoff during the simulation period was estimated in this study, and the problems were negligible.

It was important to calibrate the model and validate results against field data in order to obtain confidence in the predictive capability of the empirical model. Unfortunately, in reality, such ideal data for any watershed are impossible to obtain and L-THIA outputs cannot be compared against field data to assess model performance, especially in developing countries. Nevertheless, the effectiveness of L-THIA had been demonstrated in several studies (Ogden 1996; Bhaduri et al. 1997; Grove 1997; Minner et al. 1998; Leitch and Harbor 1999). These authors compared long term runoff calculated by L-THIA with streamflow monitoring data and found that L-THIA tended to underestimate runoff volume. Since the main objective of this study was to provide information for decision-making and long-term land-use planning, not daily series of runoff and drainage system construction, this shortage of data can be permitted in order to obtain valuable information on longterm hydrologic impacts of land-use changes.

Only two periods were considered to assess the land-use change and impact coefficients on NPS pollutants in this study. In order to further explore different impact strengths between land-use categories, more periods should be considered in future studies.

\section{Implications for land-use planning and water quality maintenance}

According to the Yearbook of Lijiang Environment Protection Bureau, the water quality of Lugu Lake is in class I, but degradation such as eutrophication has started since tourism developed and became the main industry in the watershed after 1995. The degradation in water quality results from both point source (PS) and NPS pollution. NPS pollution is not the primary source in Lugu Lake watershed; however, it should receive more attention, since the economic and technical control of NPS pollution is more difficult than PS pollution (Bhaduri et al. 1997). The results of this study provide useful information for the Lugu Lake water quality maintenance that can be used to raise decision maker's awareness of potential long-term impacts of landuse change so that policy can be developed to mitigate or minimise negative impacts. The land-use change and impact on runoff and NPS pollution found in this study imply that the following issues should be considered by decision makers or urban planners:

1. Residential and agricultural land development along the edge of the watershed is a greater threat to lake water quality;

2. Residential and agricultural land should be developed far from the waterside and their areas should not be increased in the absence of controls;

3. Forest and grass/pasture land should be developed around lakes and rivers and the Grain-for-Green programme should be rapidly implemented; and

4. PS pollution also needs to be controlled using common techniques, such as wastewater treatment plants.

In order to balance economic and environmental benefits in Lugu Lake watershed, many practices should be implemented, besides management to control NPS pollution with continuing tourism development. For example, the collection and treatment of wastewater from residential and 
tourism establishments should be enhanced so that the discharge of municipal wastewater does not move directly into Lugu Lake and surrounding rivers. Waste or garbage from residential and tourism establishments should be regularly cleaned up for example, every day. Domestic animals, such as horses, cows and sheep, should be prevented from feeding around lake coastal areas.

\section{ACKNOWLEDGEMENTS}

The authors would like to thank all partner members and institutions. This project is supported by the Development Plan of the State Key Fundamental Research of China (No. 2007CB407307) a key grant from the National Natural Science Foundation of China (No. 70325002).

\section{REFERENCES}

Basnyat P, Teeter LD, Flynn KM and Lockaby BG Relationships between landscape characteristic and nonpoint source pollution inputs to coastal estuaries. Environmental Management 1999;23(4): 539-49

Bhaduri B, Grove M, Lowry C and Harbor J. Assessing the long-term hydrologic impact of land use change. Journal of the American Water Works Association 1997;89(11):94-106

Bhaduri B, Harbor J, Engel B and Grove M. Assessing catchment-scale, long-term hydrologic impacts of land-use change using a GIS-NPS model. Environmental Management 2000;26(6):643-58

Borah DK and Bera M. Watershed scale hydrologic and nonpoint source pollution models: review of mathematical bases. ASAE 2003;46(6):1553-66

Conway TM and Lathrop RG. Alternative land use regulations and environmental impacts: assessing future land use in an urbanizing watershed. Landscape and Urban Planning 2005;71:1-15

Engel B. L-THIA GIS extension manual version 2.3. 2003; http://www.ecn.purdue.edu/runoff/ L-THIAnew/gis/L-THIAman23.pdf

ESRI. ArcGIS 8.1. Environmental Systems Research Institute Inc., Redlands, California; 2001

ESRI. ArcView 3.2. Environmental Systems Research Institute Inc., Redlands, California; 1999

Fisher DS, Steiner JL, Endale DM, Stuedemann JA, Schomberg HH, Franzluebbers AJ and Wilkinson SR. The relationship of land use practices to surface water quality in the Upper Oconee Watershed of Georgia. Forest Ecology and Management 2000; 128:39-48

Fu BJ and Gulinck H. Land evaluation in an area of severe erosion: the Loess Plateau of China. Land Degradation and Rehabilitation 1994;5:33-40

Grove M. Development and application of a GIS-based model for assessing the long-term hydrologic impacts of land-use change. MS thesis, Purdue University; 1997
Harbor J. A practical method for estimating the impact of land use change on surface runoff, groundwater recharge and wetland hydrology. Journal of the American Planning Association 1994; 60(1):95-108

Leitch $\mathrm{C}$ and Harbor J. Impacts of land use change on freshwater runoff into the near-coastal zone, Holetown Catchments, Barbados: Comparisons of long-term to single-storm effects. Journal of Soil and Water Conservation 1999;3:584-92

McClintock KA, Harbor JM and Wilson TP. Assessing the hydrological impact of land use in wetland watersheds: a case study from northern Ohio, USA. In McGregor DFM and Thompson DA (eds), Geomorphology and land management in a changing environment. Chichester: John Wiley; 1995; 107-19

McKillop R, Kouwen N and Soulis ED. Modeling the rainfall-runoff response of a headwater wetland. Water Resources Research 1999;35 (4):1165-77

Minner M, Harbor J, Happold S and Michael-Butler P. Cost apportionment for a storm water management system: differential burdens on landowners from hydrologic and area-based approaches. Applied Geographic Studies 1998;2:247-60

Novotny V and Olem H. Water quality. New York: Van Nostrand Reinold; 1994:1054 pp.

Ogden M. Development and land-use changes in Holetown, Barbados: Hydrologic implications for town planning and coastal zone management. Master of Urban Planning thesis, McGill University, Montreal, Quebec, Canada; 1996:153 pp.

Pandey S, Gunn R, Lim KJ, Engel BA and Harbor J. Developing a web-based tool to assess long-term hydrologic impacts of land use change. Journal of the Urban and Regional Information Systems Association 2000;12(4):5-17

Pauleit S, Ennos R and Golding Y. Modeling the environmental impacts of urban land use and land cover change: a study in Merseyside, UK. Landscape and Urban Planning 2005;71:295-310 
Perry J and Vanderklein E. Water quality management of natural resources. Cambridge MA: Blackwell Science; 1996:639 pp.

Ren W, Zhong Y, Melilgrana J, Anderson B, Watt WE, Chen J and Leung H. Urbanization, land use, and water quality in Shanghai 1947-1996. Environment International 2003;29:649-59

Tang Z, Engel BA, Pijanowski BC and Lim KJ. Forecasting land use change and its environmental impact at a watershed scale. Journal of Environmental Management 2005

Uchida E, Xu JT and Rozelle S. Grain for Green Cost-effectiveness and Sustainability of China's Conser vation Set-aside Program. http://www.agecon. ucdavis.edu/facultypages/rozelle/pdfs/ Uchida-Xu-Rozelle-2004.pdf

Viessman W and Hammer MJ. Water supply and pollution control. New York: Harper Collins; 1993
Wan GJ. The geochemical principles for environmental quality. Beijing: Environment Science Press; 1988: $1-216$

Wang X. Integrating water-quality management and land-use planning in a catchments context. Journal of Environment Management 2001;61:25-36

Wang Y and Deal BM. Long-term impacts of land-use change on non-point source pollutant loads for the St. Louis Metropolitan Area, USA. Environmental Management 2005;35(2):194-205

Yin ZY, Walcott S, Kaplan B, Cao J, Lin W, Chen M, Liu

$\mathrm{D}$ and Ning Y. An analysis of the relationship between spatial patterns of water quality and urban development in Shanghai, China. Computers, Environment and Urban Systems 2005;29:197-221 